\title{
Struggle ahead over abolition of academic tenure in Britain
}

\section{London}

AcADEmics in the United States have expressed their support for their British colleagues in their fight against the legislation proposed by the government which would allow senior academics to be dismissed and replaced with junior staff purely for economic reasons. At the 74th annual meeting of the Association of American University Professors (AAUP) in Washington DC, a motion was passed urging the British government to withdraw this proposal and the proposal to abolish the system of tenure in universities, which, say the AAUP, has an "ultimate relationship" with academic freedom. The AAUP "deplore" the government's disregard for that relationship.

As the Education Reform Bill reaches its report stage in the House of Lords this week the British government is not expected to back down on the plans to abolish tenure. But neither is it likely to oppose the amendment successfully tabled by the opposition which gives statutory protection to academic freedom (Nature 333, 289; 1988). The Secretary of State for Education and Science is reported to be able "to live with" the

\section{AIDS vaccine trials to begin in Geneva}

\section{Paris}

THE Swiss drug company Ciba-Geigy AG has announced imminent plans to start human safety trials of a potential vaccine against the AIDS virus. According to Pablo Valenzuela, deputy director of research at the California-based company, Chiron Corporation, which is a joint partner in the project, the vaccine uses part of the virus envelope protein, GP120, with "a special adjuvant". The decision to test the preparation in man follows pre-clinical animal trials on several species in which a strong immunological response was apparently observed.

The vaccine is to be tested on 25 healthy male volunteers at a Geneva hospital, part of Ciba-Geigy's network of Swiss contacts for clinical trials. Valenzuela says that similar trials are scheduled to begin in the United States "before the end of the year". The so-called "phase 1 safety trials" aim to see whether the vaccine produces antibodies to HIV (human immunodeficiency virus) in man and at what levels. Although GP120 has been shown to elicit an immunological response in sub-human primates, there is still no evidence that it provides effective protection against HIV infection.

Peter Coles

\section{amendment.}

This amendment, combined with the government amendments to set up grievance and disciplinary procedures, has satisfied the Committee of Vice Chancellors and Principals (CVCP) that academics will retain academic freedom.

The main matter which remains to be resolved this week is the terms of redundancy. Under the present form of the bill, and in accordance with the Governments expressed intention, "expensive" university academics may be made redundant and be replaced by a "cheaper" person to do the same work. This puts those staff at a disadvantage compared with all other employees in the country under the Employment Protection Consolidation Act (1978), including academic staff in other institutions of higher education. The CVCP considers this "grossly unfair."

Opposition has come from all parties in the House of Lords. The Conservative peer, Lord Beloff, is leading an amendment which would not allow redundancy under these terms. Another amendment proposes that the redundancy provisions be brought into line with the Act.

Another amendment likely to cause some debate in the Lords' two-day sitting with the bill is the government's amendment which gives university commissioners the power to draw up disciplinary procedures to deal with complaints relating to the appointment or employment of academic staff. An amendment is being tabled by the opposition to the effect that the onus would be on the university to prove there is good reason for dismissal before taking action. The amendment is backed by the Association of University Teachers, which represents more than 31,000 rank-and-file academics. The AUT considers this more important than allowing academics to use grievance procedures to redress unfairness. In that type of procedure the academic can receive compensation but is rarely reinstated, said the AUT.

Another problem with the bill which may cause the government some difficulty is one they appear to have brought upon themselves: abolition of tenure could quite possibly upset their programme of restructuring in university departments. Under the present form of the bill, staff with tenure lose it only if they change position. So staff are unlikely to agree willingly to reshuffling when this would bring loss of tenure. An amendment has been tabled which would mean that if academics moved in compliance with restructuring plans they should be exempt from loss of tenure.

That would have far-reaching effects as departments in line for review include physics, chemistry, biology, dentistry and accounting. A review of Earth sciences departments was recently completed. The final cost of the full restructuring programme may be more than the government expected. Last week university vice chancellors asked for another $£ 50$ million to aid the process. The government has already allocated $£ 155$ million over a period of three years to the universities for this purpose.

Christine McGourty

\section{German education takes up a lifetime}

\section{Munich}

New data from the Wissenschaftsrat, West Germany's science advisory council, reveal that in the natural sciences and engineering, a German university education may take the better part of a lifetime. The council released similar results for the social sciences and humanities at the end of April. In engineering, students completed a

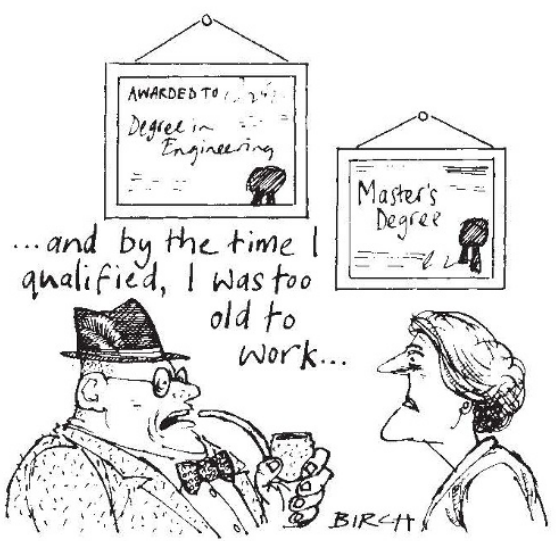

master's course in an average of 13 university terms, three terms longer than the universities recommend. The figures are complete to the end of 1985 .

Government student loans run out after 10 terms. Only 10 per cent of engineering students completed their studies in the recommended time. The average age of graduates was 28 for master's students and 33 for students with doctoral degrees.

In the natural sciences, the results (to the end of 1985) were much the same. But wide variations showed up among the different universities. In Constance, for instance, physics and biology students completed their studies in an average of fewer than $\mathbf{1 0}$ university terms. In Berlin's Free University, by contrast, students completed a master's in physics in $\mathbf{1 4 . 6}$ terms and in biology in 14.2 terms. At the Technical University of Berlin, a physics master's degree took 16.6 terms, the highest average of all universities for physics.

Only 5 per cent of physics graduates were women compared with 47 per cent of biology graduates.

Steven Dickman 